\title{
B4GALT1 Gene
}

National Cancer Institute

\section{Source}

National Cancer Institute. B4GALT1 Gene. NCI Thesaurus. Code C104851.

This gene plays a role in carbohydrate synthesis. 